\title{
Attitude of Students toward Entrepreneurship Studies in the University of Calabar, Cross River State
}

\author{
Otu, Bernard Diwa ${ }^{1}$, Eduwem, Joy Dianabasi ${ }^{2}$, Umoinyang, Imo Edet ${ }^{3}$ \\ ${ }^{l}$ Department of Educational Foundations, University of Calabar, Calabar \\ ${ }^{2}$ School of Health Information Management, University of Calabar Teaching Hospital, Calabar \\ ${ }^{3}$ Institute of Education University of Calabar, Calabar
}

\begin{abstract}
This study was designed to investigate the attitude of students towards entrepreneurial studies in the University of Calabar, Cross River State, Nigeria. To achieve this purpose, one hypothesis was formulated and a Survey research design was adopted for the study. A sample of two hundred and twenty five (225) respondents was randomly selected from a population of 20193 of the undergraduate students of the University of Calabar as at 2014/2015 academic session. The selection was done through the stratified random sampling technique. The questionnaire was the main instruments used for data collection. The reliability estimate of the instrument was established using the Cronbach alpha estimate. Population t-test was employed to test the hypothesis at .05 level of significance. The result of the analysis revealed that, students' attitude towards entrepreneurial studies is significantly positive. Based on the findings of the study, it was concluded that undergraduates in Universities in Nigeria are favourably disposed to entrepreneurial studies. It is recommended among others thatentrepreneurship development in Nigerian tertiary institutions should adopt entrepreneurial learning as entrepreneurship development method. Also, students should be mixed during entrepreneurship programmes with recourse to their level of creativity.
\end{abstract}

\section{Background to the study}

A major cause of poverty in most societies is the high unemployment level. In the Nigerian society in the past, jobs were instant and people, especially the educated had no need for self - employment since they could get well paid job at ease. But in recent times experience of unemployment has pushed people to think entrepreneurship and the creation of one's own business as the only alternative for survival by people irrespective of their educational background (Allawadi, 2010). As a result of the socio-economic hardship and embarrassment of unemployment, many people have changed their orientation and values, in favour of owning businesses after graduation from an educational institution. It is observed that since then there has been an increase in business ownership in general and within the educated class in particular, especially small and medium scale businesses (Armington, 2002). This is clearly evident among the youths who are the worst hit by the country's unemployment situation.

One would observe that there are more youths who now than ever before own businesses in all aspect of industry. The growth in the service, fashion designing, dry cleaning and hospitality/entertainment industry as well as commerce is atestament to this (Awogbenie \& Iwuamadi, 2010). This may not be because they lacked adequate skills and experiences yearly, which has resulted in them not being able to get job in the labour market.The situation of young people in the labour market is aggravated by the fact that the formal labour market is still very small in Nigeria as a whole. Young people are often at the end of the job queue because the educational institutions are producing more graduates yearly who have adequate skills but lack experience, as well as efficient social networks. A significant number of young people are discouraged by an unsuccessful job search and leave the formal workforce entirely. The situation of graduate unemployment has been a serious problem owing to the fact that many that graduated have not been able to get any job in the labour market. With the increasing demand for higher education they have been the problem of suitable employment for the varieties of graduates who are turned out by these institutions every year. Ordinarily, this should have been a problem, but the reality is that the Nigerian economy is too weak to absorb this large number of graduates (Uromi, 2011). Furthermore, there is no vibrant manufacturing sector which has the capacity to absorb the unemployed youths in Nigeria.According to Armington (2002) a number of factors inhibit the desire of many Nigerian graduates to own their businesses in practical terms which include Finances/Capital, environmental factors and nature of businesses. However, behaviour modification and conditioning, involves learning and value orientation. These, according to him, help create the necessary entrepreneurial personality. In this regard, graduate orientation in recent time is changing. A lot of graduates are beginning to think in the direction of owning their business and be self - employed in whatever areas of business they can find opportunities(Salami, 2009). This changing attitude and orientation is basically due to the challenges of economic realities in terms of unemployment, which have confronted them in present times, leaving them with no alternative for survival, other than self - 
employment. With the soaring unemployment rate in Nigeria, like every other developing economy, self employment and small enterprise initiative are presently high on the country's national agenda, in the hope that they will provide alternative channels of employment. Yearly, thousands of university graduate join the labour market in search of gainful employment. Underlying this situation is the fact that the training which tertiary students receive has not been fully successful in equipping them with desirable skills andcompetenciesrequired for job creation and self - employment(Madumere-Obike, 2006; Amaeolule, 2007; Nwangwu, 2007). The realization of this critical fact underlies the directive of the Federal Government of Nigeria to all tertiary education regulatory agencies to establish necessary mechanisms for the introduction, development and sustenance of entrepreneurial culture among Nigerian youths.To make up for the curricular inadequacies in meeting employment problem, the National Universities Commission (NUC) in July 2004, organized a workshop on entrepreneurship for Nigerian Universities as a way forward. The NUC workshop produced a draft curriculum on entrepreneurship studies for Nigeria universities. Consequently, many universities have initiated entrepreneurship education programmes in an attempt to reverse graduate unemployment trend by giving the needed training in entrepreneurial skills to student for setting up businesses and to consider self - employment as a viable career option.

Entrepreneurship education according to Isaac, Visser, Fredrick and Briflal (2007) is a purposeful intervention by an educator in the life of the learner to survive in the world of business. It has its focus on action orientation primarily embodied in teaching students how to develop a business plan (Ronstadl, 1985). Entrepreneurship education develops and stimulates entrepreneurial process, providing all tools necessary for starting up new ventures (Postigo \& Tombonni, 2002). It is commonly believed that entrepreneurship education isan imperative that would make a positive contribution to improving the entrepreneurship orientation of people, leading to the acquisition of skills, creativity, confidence, drive and courage in order to create employment for self and others (Umoinyang, 2009).

It is however believed that a strong positive link exists between students' perception of entrepreneurial studies and their business ownership aspiration which appears to be conclusive from the studies conducted in some parts of Cross River State and elsewhere. None of the studies however utilized entrepreneurial studies and business ownership aspirations in the whole state. It is against this background that this study is aimed in determining students' perception of entrepreneurial studies and their business ownership aspiration in Universities of Calabar, Calabar, Cross River State, Nigeria.

\section{Research Methodology}

The research design adopted for this study was ex-post facto design. Isangedighi, Joshua, Asim and Ekuri (2004) assert that ex-post facto research design is a systematic empirical inquiring in which the researcher does not have direct control of independent variables because their manifestations have already occurred or manipulated. Inferences about relations among variables were made without direct intervention from concomitant variation of independent and dependent variables. The population of this study consisted of all the under graduate students in University of Calabar. There were 20193 students as recorded by Academic planning unit of the university 2014/2015.The sampling technique adopted for this study was thestratified random sampling technique.The sample of this study consisted of two hundred and twenty-five (225) undergraduates randomly selected from five departments in the University.

The main instrument used for data collection was the questionnaire, Students' attitude towardsentrepreneurial studies questionnaire (SATESQ), designed by the researchers. The questionnaire is a 15 item 4 - point Likert type of scale. The respondentsare to indicate the extent of their agreement to the statements. The reliability of the research instrument was established through Cronbach reliability estimation using fifty (50) students drawn from the university and an index of .89 was obtained. This value was considered very to qualify the questionnaire for use in the actual data collection. The questionnaire was administered personally by the researchersto the sampled students in their departments. The instrument was retrieved the same day they were administered. Data collection lasted for one week. At the end of the exercise, all questionnaire administered were successfully completed and retrieved from the sample.

\section{Presentation of result \\ Hypothesis}

Students' attitude towards entrepreneurial studies is not significantly positive.

This hypothesis consists of only one variable which is students' attitude towards entrepreneurial studies. Population t-test (also known as one sample t-test) analysis was adopted to test this hypothesis. The result is presented in Table 1. 
TABLE 1

Population t-test analysis of students' attitude towards entrepreneurial studies $(\mathrm{N}=225)$

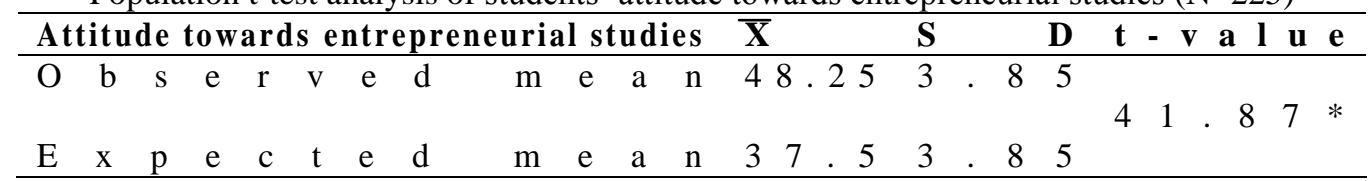

* Significant at .05 level, critical $\mathrm{t}=1.96, \mathrm{df}=224$.

The result in Table 1 revealed that the calculated t-value of 41.87 is higher than the critical t-value of 1.96 required for significance at 0.05 level of significance with 224 of degrees of freedom. Thus the null hypothesis that Students' attitude towards entrepreneurial studies is not significantly positive was rejected. This result shows that students have a significant positive attitude towards entrepreneurial studies.

\section{Discussion of Findings}

The result of this study revealed that students attitude towards entrepreneurial studies is significantly positive. The result is not surprising because the students are familiar with the unemployment trend in the society and would not want to be members of the unemployed class. Some of the students at the moment are involved in some form of merchandise for survival. The findings of this hypothesis is in line with the view of Kruger, Reilly and Carsrud (2000) who observed that attitude impacts the expression of specific behaviors and depends on the individual's positive or negative beliefs about and estimations of said behaviors. It is an expression of emotion that is translated into the individual's actions. They also stated that attitude denotes the students' beliefs and views towards entrepreneurship as assessed in a validated questionnaire. This may imply, as applied in this study, the propensity of the respondents to engage in entrepreneurial work at some period in their life, either while studying in college, or later after finishing their degree.

Entrepreneurship has been a buzzword, especially among young people between the ages of 18-34. They have recognized the various benefits of starting-up new businesses. The motivations for business start-ups among potential women entrepreneurs are driven mostly by the 'self-achievement desire', 'need for more money' and 'desire for a higher social and professional status'.Entrepreneurs demonstrate a need to achieve, a willingness to exploit a challenge, to persevere, to work hard and driven by self-belief, but tempered with the ability to be flexible and to delegate to others when necessary as well as willingness to listen to advice and to recognize that they are not experts in every aspect of their business. The students feel that they should be independent as asserted by Allen (2006) that entrepreneurs do not wait for someone else to take the decision, or solve the problem, or even ask for the problem to be solved; they recognize problems as opportunities and takes it upon themselves to solve them.

\section{Recommendations}

Based on the finding of this study the following recommendations were made:

1. Entrepreneurship development in Nigeria tertiary institutions should adopt entrepreneurial learning as entrepreneurship development method. Also, students should be mixed during entrepreneurship programmes with recourse to their level of creativity.

2. Government, in addition to the guideline to introduce entrepreneurship programmes in tertiary institutions should provide financial backing the sustain students' involvement in the program.

3. Entrepreneurial training in all the tertiary institutions should be specific and practical to enable the participants maximally benefit from it.

\section{References}

[1]. Allawadi, S. C. (2010). Entrepreneurship Challenges in 21st Century. Mumbai: Indian Institute of Materials Management.

[2]. Amaewhule, W. A. (2007). Education, the world of work and the challenge ofchange: In search of intervention strategies. Inaugural lecture series No 23; River State University of Science and Technology, Nkpolu, Port Harcourt.

[3]. Armington, B. (2002). Entrepreneurship development and employment generation in Nigeria: Problems and prospects. Universal Journal of Education and General Studies, 1(4), $88-102$

[4]. Awogbenie, E. \& Iwuamadi,I. (2010). A longitudinal study of the entrepreneurial intentions of University students. Academy of entrepreneurship Journal, 10(2), 3 - 16.

[5]. Bassey, U. U., \& Archibong, I. A. (2005). Assuring quality graduate output through entrepreneurial oriented education in NigerianUniversities. Nigerian Journal of Curriculum Studies, 12(3), 18-23.

[6]. Cotton, J., O’Gorman, C. \& Stampfi, C.(2005). Can national education policies meet the call for more entrepreneurs? A project supported by the European community(project no - FIN/00/C/P/RF/92650) (www.google.com); March, 2005.

[7]. European Union. (2002). Final report of the expert group "Best procedure" project on Education and Training for Entrepreneurship. Brussels: European Commission Directorate - General for enterprise.

[8]. Isaac, E., Visser, K., J Frederick C.\& Brijlal, P. (2007). Enterpreneurship educationand training at the further education and training(FET) level in South Africa. South African Journalof Education, 27, 613-629. 
[9]. Isangedighi, A. J., Joshua, M. T., Asim, A. E., \& Ekuri, E. E. (2004). Fundamentals of research and statistics in education and social sciences. Calabar: University of Calabar Press

[10]. Krueger, N. F. Dr., Reilly, M. D. \& Carsrud, A. I. (2000). Competing models of entrepreneurial intentions. Journal of Business Venturing, 15, $411-432$.

[11]. Madumere-Obike, C.U. (2006). Repositioning education for employment:Implications for educational management. Muldisciplinary Journal of Research Development 7(9), $81-93$.

[12]. Postigo, T.\& Tambonni, M. F.(2002). Entrepreneurship Education in Argentina: the case of San Andres University. Paper presented for internationalizing Entrepreneurship Education and Training Conference (INTENT, 2002), Malaysia, July 8-10.

[13]. Ronstadt, R. (1985). The Educated Entrepreneurs: A new era of Entrepreneurial Education is beginning. American Journal of Small Business, 10, 7-23.

[14]. Salami, C.G.E. (2009). Assessment of QualityAssurance in Nigerian Universities

[15]. Umoinyang, I. E. (2009). Entrepreneurial development for youths in secondary schools. Guest lecture at Access Schools, Calabar during the 2009 graduation ceremony. 